\title{
Efektivitas penggunaan alat peraga sederhana berbasis pendekatan sains teknologi masyarakat pada materi fluida statis
}

\author{
Suci Prihatiningtyas, dan Ino Angga Putra \\ Universitas KH. A. Wahab Hasbullah \\ J1. Garuda No.09 Tambakberas Jombang \\ Surat-e: suci.ningtyas4317@gmail.com
}

Berdasarkan hasil wawancara dan observasi langsung yang dilakukan oleh peneliti di program studi pendidikan fisika KH. A. Wahab Hasbullah, diketahui bahwa program studi tersebut belum memiliki alat peraga yang mampu membantu mahasiswa memperoleh pengalaman belajar secara langsung melalui praktikum sehingga hasil belajar yang diperoleh masih rendah. Penelitian ini bertujuan untuk mendeskripsikan efektivitas penggunaan alat peraga sederhana berbasis pendekatan sains teknologi masyarakat pada materi fluida statis. Metode penelitian yang digunakan adalah deskriptif kuantitatif dengan pendekatan pra-eksperimen One Group Pretest-Posttest Design pada mahasiswa pendidikan fisika semester genap tahun ajaran 201720I8. Teknik penumpulan data berupa lembar pengamatan RPP dan aktivitas, tes hasil belajar serta angket respon mahasiswa. Berdasarkan hasil penelitian dan pembahasan dapat disimpulkan bahwa pembelajaran dengan menggunakan alat peraga sederhana berbasis pendekatan sains teknologi dan masyarakat pada materi fluida statis dapat efektif diterapkan pada mahasiswa. Hal ini dilihat dari hasil keterlaksanaan RPP yang berkategori baik, aktivitas mahasiswa yang dominan melakukan praktikum, hasil belajar mahasiswa rata-rata memiliki nilai 82 , respon mahasiswa yang sangat baik terhadap penggunaan alat peraga sederhana fluida statis.

Based on the results of interviews and direct observations made by researchers in the physics education program $\mathrm{KH}$. A. Wahab Hasbullah, it is known that the study program does not have visual aids that are able to help the students gain direct learning experience through practicum so that the learning result obtained is still low. This study aims to describe the effectiveness of the use of simple visual aid based on the approach of community science technology on static fluid materials. The quantitative descriptive research method is used with a pre-experimental approach of One Group Pretest-Posttest Design on a physics education student second semester of the academic year 2017-2018. Data collection techniques are RPP observation sheets and activity, a test of learning result and student response questionnaire. Based on the results of research and discussion it can be concluded that learning by using simple visual aid based on science and technology approach of society on the static fluid material can be effectively applied to students. This is seen from the results of the implementation of RPP is categorized well, the student activity is dominant in practicum, student learning outcomes on average has a value of 82 , excellent student response to the use of simple static fluid visual aid.

Kata kunci: alat peraga sederhana, pendekatan sains teknologi masyarakat, fluida statis

\section{Pendahuluan}

Fisika dasar merupakan salah satu mata kuliah yang wajib ditempuh oleh mahasiswa di semester awal perkuliahan. Hal ini dikarenakan fisika dasar sebagai bekal mereka untuk mempelajari ilmu-ilmu fisika lainnya yang lebih kompleks. Oleh karena itu, mata kuliah fisika dasar harus mampu memberikan pemahaman kepada mahasiswa sehingga kemampuan kognitif mahasiswa berkembang. 
Salah satu materi yang terdapat dalam fisika dasar adalah mekanika fluida. Mekanika fluida terdiri dari dua pembahasan yaitu fluida statis dan dinamis. Dalam kehidupan sehari-hari yang sering kita jumpai salah satunya yaitu tentang penerapan dari fluida statis. Konsep fluida yang sering diterapkan dalam kehidupan sehari-hari antara lain rem hidrolik, pompa hidrolik, dongkrak hidrolik, dan pembuktian keaslian suatu bahan (menggunakan hukum Archimedes) sehingga dianggap perlu untuk memberikan pengalaman langsung dalam proses pembelajaran untuk membantu mahasiswa menguasai materi secara tuntas.

Pembelajaran fisika diharapkan akan lebih menyenangkan dan mudah dipahami oleh mahasiswa jika disertai dengan kegiatan praktikum. Hal itu akan membuat mahasiswa lebih dekat dengan laboratorium dan mengenal berbagai peralatan kerja praktikum yang ada di dalamnya.

Berdasarkan observasi dan wawancara yang dilakukan kepada mahasiswa pendidikan fisika Fakultas Ilmu Pendidikan Universitas KH. A. Wahab Hasbullah, pengetahuan mahasiswa tentang alat-alat praktikum yang sering digunakan di laboratorium masih belum optimal. Hal ini dikarenakan belum adanya laboraturium yang memadai untuk melakukan praktikum. Pembelajaran di kelas lebih kepada penyampaian materi secara langsung (model pembelajaran langsung). Hal ini menjadikan mahasiswa kurang terkesan dalam memahami dengan materi yang disampaikan.

Pembelajaran akan lebih mudah dipahami oleh mahasiswa jika proses pembelajaran menyenangkan selain penyampaian materi yang menyenangkan tetapi kegiatan pembelajaran harus dilakukan praktikum. Hal ini dikuatkan oleh Pustaka $[\mathrm{I}]$ yang berpendapat bahwa pembelajaran IPA akan berhasil jika ditunjang dengan kegiatan praktikum. Tersedianya laboratorium untuk kegiatan praktikum diharapkan dapat mengajarkan keterampilan kognitif, psikomtor dan afentif dari mahasiswa.

Keterampilan kognitif mahasiswa diperoleh dari pemahaman mereka tentang konsep fisika yang diajarkan meliputi mengobservasi, menafsirkan hasil observasi, dan menyimpulkan. Keterampilan psikomotor mahasiswa diperoleh dari keterampilan dalam menggunakan alat. Keterampilan afektif diperoleh dari sikap mahasiswa dalam melaksanakan praktikum misalnya cara mereka bertanggung jawab, ketelitian, kejujuran dan sikap yang lainnya.

Ketidak tersedianya laboraturium dan alat praktikum di prodi pendidikan fisika, menuntut dosen lebih kreatif dan inovatif dalam merancang dan mengolah pembelajaran. Selain dosen memiliki pengetahan luas dalam penguasaan materi tetapi dosen harus mampu menciptakan metode dan media pembelajaran guna menunjang proses pembelajaran. Salah satu contoh media yaitu dengan pembuatan alat peraga. Alat peraga adalah suatu alat bantu yang digunakan dalam pembelajaran dengan memanfaatkan barang disekitar yang sudah tidak dapat digunakan lagi. Alat peraga diharapkan dapat digunakan sebagai alternatif praktikum jika alat praktikum tidak memadai. Tujuannya agar proses belajar mengajar membuat mahasiswa merasa senang, menarik dan tetap menguasai materi yang diajarkan sehingga dapat memahamkan konsep fisika yang bersifat abstrak.

Panca indera manusia mampu menerima atau menanggkap suatu pengetahuan dengan adanya alat peraga. Adanya alat peraga diharapkan mampu mengarahkan panca indera untuk memahami suatu konsep [2]. Hal ini sesuai dengan teori kode ganda (Dual Code Theory) yang dikemukakan oleh Pavio. Hipotesa Pavio, informasi yang tersimpan dalam memori jangka panjang manusia yaitu informasi visual (dilihat) maupun verbal (didengar). Informasi yang disampaikan secara visual dan verbal akan diingat lebih baik dari informasi yang disajikan melalui komunikasi visual atau verbal saja.

Alat peraga sederhana dapat dibuat dengan memanfaatkan barang bekas yang ada disekitar kita dan tidak digunakan lagi. Barang bekas yang dipakai adalah plastik. Upaya pembuatan alat peraga dari bahan bekas dapat menerapkan suatu pendekatan pembelajaran yang mampu memperbaiki segala bentuk kekurangan yang ada dalam proses pembelajaran fisika. Salah satunya melalui pendekatan pembelajaran Sains Teknologi Masyarakat (STM). Pendekatan Sains Teknologi Masyarakat memadukan antara sains teknologi dan isu-isu yang berkembang di masyarakat. Sebagai warga negara yang baik maka guru perlu mengajarkan kepada siswa untuk tanggap terhadap teknologi, dapat mengetahui dampak positif dan negatif dari kemajuan teknoogi sehingga mereka bijaksana dalam mengambil keputusan untk mensejahterakan masyarakat [3].

Penelitian yang terkait dengan penerapan alat peraga adalah penelitian Pustaka [2] yang mengatakan bahwa hasil belajar siswa setelah mengikuti pembelajaran dengan menggunakan media alat peraga kit fluida mengalami kenaikan sehingga diperoleh persentase ketuntasan hasil belajar secara klasikal mencapai $85,80 \%$. Skor perkembangan (gain skor) mencapai 0,8 dengan kriteria tinggi. Pustaka [4] menyatakan bahwa alat peraga sederhana berbasis teknologi daur ulang dapat meningkatkan pemahaman konsep fisika siswa pada materi vektor di SMKN I Wonoasri tahun pelajaran 20I4/20I5 dengan nilai gain rata - rata 0,9I. Pustaka [5] mengemukakan bahwa penggunaan alat peraga bahan bekas dalam pembelajaran system respirasi manusia dapat meningkatkan prestasi belajar siswadi MAN Sawang Kabupaten Aceh Selatan. Hasil penelitian Siarni mengatakan bahwa pemamfaatan barang bekas 
sebagai media dapat meningkatkan hasil belajar IPA siswa kelas IV SDN 07 Salule Mamuju Utara.

Berdasarkan uraian di atas, maka peneliti hendak mengadakan penelitian yang berjudul "Efektivitas Penggunaan Alat Peraga Sederhana Berbasis Pendekatan Sains Teknologi Masyarakat Pada Materi Fluida Statis"

\section{Kajian Pustaka}

\section{Pengertian Alat Peraga}

Kata "Alat Peraga" diperoleh dari dua kata alat dan peraga. Kata utamanya adalah peraga yang artinya bertugas "meragakan" atau membuat bentuk "raga" atau bentuk "fisik" dari suatu arti/pengertian yang dijelaskan. Bentuk fisik itu dapat berbentuk benda nyatanya atau benda tiruan dalam bentuk model atau dalam bentuk gambar visual/audio visual. Alat peraga dapat dimasukkan sebagai bahan pembelajaran apabila alat peraga tersebut merupakan desain materi pelajaran yang diperuntukkan sebagai bahan pembelajaran. Fungsi utamanya adalah untuk menurunkan keabstrakan konsep agar siswa mampu menangkap arti konsep tersebut. Alat peraga atau alat bantu adalah alat pelajaran yang dipakai guru untuk menerangkan atau memperjelas materi pelajaran agar murid dapat lebih mudah mengerti, lebih tertarik dan lebih cepat memahami. Alat bantu merupakan salah satu komponen yang mendukung poses belajar mengajar. Kedudukannya sama dengan media pembelajaran.

Alat peraga merupakan media pembelajaran yang mengandung atau membawa konsep-konsep dari materi yang dipelajari [6]. Penggunaan alat peraga ini akan membantu memudahkan siswa untuk memahami suatu konsep. Sehingga dengan adanya alat peraga dalam pembelajaran secara tidak langsung akan mewujudkan kegiatan belajar yang melibatkan seluruh aspek yang dimiliki siswa melalui keaktifan fisik dan mental. Alat peraga adalah salah satu media pembelajaran yang merupakan bentuk penggambaran mekanisme kerja suatu benda. Alat peraga memiliki fungsi untuk memperagakan peristiwa, kegiatan, fenomena, atau mekanisme kerja suatu benda [7]. Alat peraga dapat memuat ciri dan bentuk dari konsep materi ajar yang digunakan untuk memperagakan materi yang berupa penggambaran mekanisasi, peristiwa dan kegiatan sehingga materi bisa lebih mudah dipahami oleh siswa. Selain itu, alat peraga dapat membuat interaksi antara siswa selama pembelajaran, karena ikut menjelaskan ulang materi dengan menggunakan media sehingga lebih dipahami. Hal yang sama dikemukakan oleh pustaka [8] yang mengatakan bahwa alat peraga merupakan media pembelajaran yang mengandung atau membawa konsepkonsep dari materi yang dipelajari. Penggunaan alat peraga ini akan membantu memudahkan siswa untuk memahami suatu konsep. Kelayakan alat peraga adalah pantas atau tidaknya alat peraga tersebut digunakan dalam pembelajaran fisika dikelas. Kelayakan alat peraga meliputi :

I) Alat peraga harus sesuai dengan konsep fisika

2) Alat peraga harus sesuai dengan kurikulum

3) Bentuk dan performa dari alat peraga harus menarik dan sesuai dengan subjek (siswa) yang hendak diteliti

4) Alat peraga mudah dipahami oleh siswa dan keterbacaan alat mudah

5) Alat peraga hendaknya mudah digunakan

\section{Pendekatan Sains, Teknologi dan Masyarakat}

Dalam menyampaikan suatu materi secara baik maka dibutuhkan suatu pendekatan dalam pembelajaran. Pendekatan diartikan sebagai titik tolak atau sudut pandang kita terhadap proses pembelajaran, pendekatan yang diharapkan adalah pendekatan yang mampu membuat siswa aktif selama proses belajar dan mengajar berlangsung. Salah satunya adalah pendekatan sains teknologi dan masyarakat. Sains teknologi dan masyarakat (Sainstekmas) adalah istilah yang diterjemahkan dari Science-Technology-Society (STS). Science-Technology-Society untuk pertama kali diciptakan oleh John Ziman dalam bukunya "Teaching and Learning About science and Society" pada tahun 1980. Dalam bukunya tersebut, Ziman mencoba mengungkapkan bahwa konsep-konsep dan prosesproses sains seharusnya sesuai dengan kehidupan siswa sehari-hari. Tujuan dari Sainstekmas bagi guru/dosen adalah agar memahami kaitan antara sains teknologi masyarakat secara positif, serta dampaknya bagi kehidupan manusia. Sains teknologi masyarakat sangat berguna bagi siapa saja dalam menemukan sesuatu yang baru dalam kehidupan masyarakat. Dengan memperkenalkan Sainstekmas kepada siswa, mereka akan memiliki kepekaan dan kesadaran yang sangat tinggi trehadap kehidupan mereka sendiri. Dengan cara melatih ketrampilan sains teknologi, mereka diharapkan bisa merancang produk-produk yang bisa bermanfaat bagi masyarakat. Mereka dapat memecahkan segala persoalan dengan tepat untuk selalu mencari alternatif baru secara progesif.

Dengan demikian, pembelajaran menggunakan sains teknologi masyarakat diharapkan lebih menyadari manfaat yang telah dipelajarinya bagi lingkungannya. Oleh karenanya, apabila terjadi kesulitan atau masalah di sekitarnya siswa akan berperan serta secara aktif menyelesaikan masalah. Sikap ini terbina oleh kegiatan yang telah dilaksanakan selama pembelajaran dengan model sains teknologi masyarakat. Pada akhirnya siswa akan menggemari untuk ikut aktif berkiprah dalam lingkungannya. Gambar I berikut adalah bagan tahaptahap implementasi pendekatan Sainstekmas: 


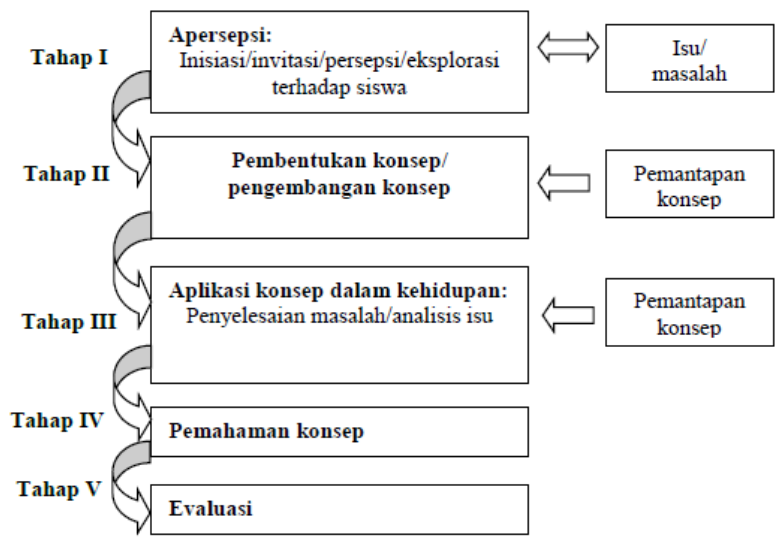

Gambar I. tahap implementasi pendekatan Sainstekmas

Sains-Teknologi-Masyarakat merupakan terjemahan dari Sains-Technogy-Society (STS), yaitu suatu usaha untuk menyajikan Ilmu Pengetahuan Alam dengan mempergunakan masalah-masalah dari dunia nyata [9]. Sainstekmas adalah suatu pendekatan yang mencakup seluruh aspek pendidikan yaitu tujuan, topik/masalah yang akan dieksplorasi, strategi pembelajaran, evaluasi, dan persiapan/kinerja guru. Pendekatan ini melibatkan siswa dalam menentukan tujuan, prosedur pelaksanaan, pencarian informasi dan dalam evaluasi. Tujuan utama pendekatan Sainstekmas ini adalah untuk menghasilkan lulusan yang cukup mempunyai bekal pengetahuan sehingga mampu mengambil keputusan penting tentang masalah-masalah dalam masyarakat sehingga dapat mengambil tindakan sehubungan dengan keputusan yang diambilnya.

\section{Metode Penelitian}

Subjek ujicoba adalah mahasiswa pendidikan fisika Fakultas Ilmu Pendidikan Universitas KH. A. Wahab Hasbullah semester genap. Penelitian ini dilaksanakan pada semester genap tahun ajaran 2017-2018. Metode penelitian destriptif kuantitatif dengan pendekatan PreExperimental. Rancangan penelitian yang digunakan adalah one group pretest-posttest design dengan pola:

\section{$\mathrm{O}_{1} \mathrm{X} \mathrm{O}_{2}$}

\section{Keterangan:}

O I adalah uji awal (pretest) untuk mengetahui penguasaan mahasiswa terhadap materi pelajaran sebelum pembelajaran berlangsung.

$\mathrm{X}$ adalah pembelajaran dengan menggunakan alat peraga fluida statis

$\mathrm{O}_{2}$ adalah uji akhir (posttest) untuk mengetahui penguasaan mahasiswa terhadap materi pelajaran setelah pembelajaran berlangsung.

Instrumen yang digunakan dalam penelitian ini adalah lembar rencana pelaksanaan pembelajaran (RPP), lembar aktivitas mahasiswa, angket respon mahasiswa, lembar tes hasil belajar dan lembar kendala dalam pembelajaran. Teknik penumpulan data berupa lembar pengamatan RPP dan aktivitas, tes hasil belajar serta angket respon mahasiswa.

\section{Hasil Penelitian dan Pembahasan}

Berdasarkan hasil penelitian diperoleh hasil sebagai berikut:

\section{Keterlaksanaan rencana pelaksanaan pembelajaran}

Kegiatan pembelajaran yang tercantum pada RPP terdiri dari kegiatan pendahuluan, kegiatan inti, penutup. Pada kegiatan ini diamati oleh dua pengamat. Nilai yang telah diberikan pengamat kemudian dihitung reliabitasnya kemudian disesuaikan dengan skala kriteria. Adapun hasil pengamatannya yaitu:

a) Kegiatan pendahuluan rata-rata pengamat memberikan nilai 3,7 dengan kategori baik. Pada kegiatan ini, dosen sudah membuka kegiatan pembelajaran dengan baik, membaca doa, memotivasi mahasiswa, menyampaikan capaian pembelajaran, indikator dan tujuan pembelajaran.

b) Kegiatan inti rata-rata pengamat memberikan nilai 3,5 dengan kategori cukup baik. Pada kegiatan ini, dosen sudah mampu mengaktifkan mahasiswa dalam kelompok. Tetapi sebagian mahasiswa masih gaduh karena masih kesulitan dalam melakukan praktikum misalnya kesulitan membaca skala ukur.

c) Untuk kegiatan penutup, rata-rata pengamat memberikan nilai 3,8 dengan kategori baik. Dosen mampu membimbing mahasiswa menyimpulkan hasil praktikum dan mengarahkan mahasiswa untuk kegiatan praktikum pada pertemuan selanjutnya.

\section{Aktivitas mahasiswa}

Aktivitas mahasiswa selama praktikum dinilai oleh pengamat. Adapun analisis aktivitas mahasiswa selama praktikum dapat dilihat pada gambar 2 berikut:

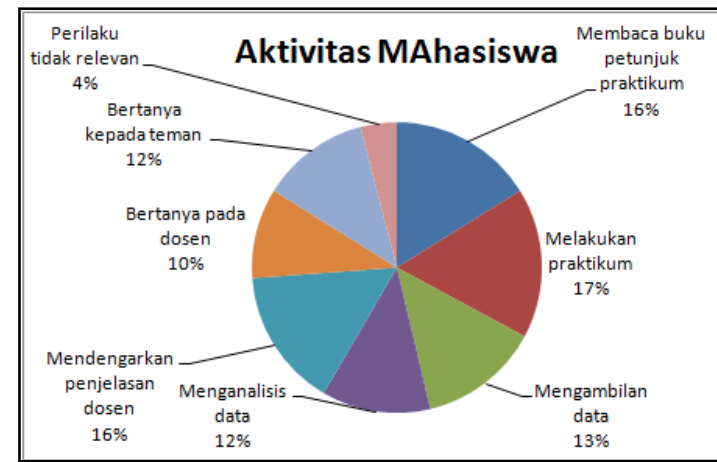

Gambar 2. Diagram aktivitas mahasiswa dalam pembelajaran di kelas 
Berdasarkan gambar 2 dapat dikemukakan bahwa persentase aktivitas siswa yang paling dominan adalah mereka melakukan praktikum. Mereka dapat melakukan pratikum secara antusias karena mereka mendengarkan penjelasan dari dosen serta membaca buku petunjuk praktikum. Meskipun mereka melakukan praktikum tetapi ada dari sebagia mereka yang melakukan perilaku yang tidak relevan misalnya bercanda mengganggu temannya dalam praktikum.

\section{Tes hasil belajar}

Tes hasil belajar bertujuan untuk mengetahui kemampuan kognitif mahasiswa setelah mengikuti pembelajaran. Pada penelitian ini dilakukan tes awal (pretes) dan tes akhir (posttes). Pada pretes rata-rata nilai mahasiswa 67 sedangkan setelah diadakan postes nilai rata-rata mahasiswa 82. Pada kegiatan pretes sebagian dari mereka lupa tentang materi yang diajarkan meskipun sebelumnya mereka telah mendapatkan materi tersebut di sekolah menengah atas (SMA). Setelah diadakan pembelajaran dengan menggunakan media alat peraga sederhana hasil belajar mahasiswa meningkat. Dengan penggunaan metode yang tepat dan penggunaan media yang praktis dalam proses belajar mengajar dapat menimbulkan semangat belajar dan suasana belajar yang menyenangkan sehingga informasi yang disampaikan oleh dosen dapat mudah diterima dan dioleh kedalam memori jangka panjang. Hal ini sejalan dengan teori Pavio tentang dual coding theory bahwa informasi yang disajikan secara visual maupun verbal diingat lebih baik daripada informasi yang hanya disajikan dengan salah satu cara. Hal ini dianggap sebagai salah satu faktor penentu hasil belajar mahasiswa meningkat karena penggunaan media dapat meningkatkan daya ingat mahasiswa sehingga perhatian dan motivasi terhadap materi pembelajaran yang dibahas lebih mudah dipahami. Pendapat ini didukung oleh hasil penelitian yang dilakukan Pustaka [7] yang mengatakan bahwa dengan alat peraga memudahkan siswa dalam memahami dan mengaplikasikan teori yang diperoleh secara langsung lebih real sehingga lebih mudah dipahami. Hal ini sejalan dengan penelitian Pustaka [5], alat peraga yang sesuai akan mendukung pembelajaran karena penyampaian isi materi pelajaran dengan menggunakan alat peraga dapat merangsang siswa untuk belajar baik tercetak maupun audio-visual. Pembelajaran dengan menggunakan alat peraga merupakan wujud perpaduan konsep yang abstrak dengan dunia nyata. Pustaka [IO] juga menyebutkan bahwa, pembelajaran menggunakan alat peraga sama artinya dengan mengoptimalkan fungsi seluruh panca indera siswa untuk meningkatkan efektivitas siswa belajar dengan cara mendengar, melihat, meraba, dan menggunakan pikirannya secara logis dan realistis. Dalam proses pembelajaran alat peraga tidak hanya sekedar alat bantu guru dalam penyampaian informasi kepada siswa tetapi dapat membuat perhatian siswa pada materi pelajaran meningkat sehingga pada akhirnya hasil belajar siswa pun juga akan lebih baik.

\section{Respon mahasiswa}

Respon mahasiswa terhadap penggunaan alat peraga sederhana dapat dilihat pada gambar 3 .

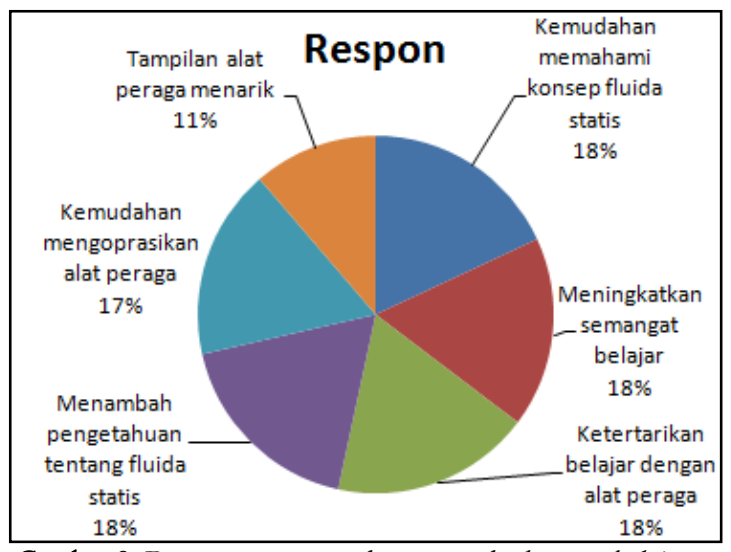

Gambar 3. Diagram respon mahasiswa terhadap pembelajaran menggunakan alat peraga sederhana.

Berdasarkan gambar 3 dapat dikemukakan bahwa respon mahasiswa terhadap pembelajaran menggunakan alat peraga sederhana termasuk kategori sangat baik. Adapun kriteria aspek penilaian respon mahasiswa meliputi pemahaman konsep fluida statis dengan penggunaan alat peraga, pengoprasian alat, dan kualitas alat peraga.

\section{Kendala yang dihadapi}

Kendala yang dijumpai selama proses pembelajaran yaitu mahasiswa masih kesulitan dalam membaca alat ukur, mahasiswa masih banyak yang bercanda dengan anggota kelompoknya.

\section{Kesimpulan}

Berdasarkan hasil penelitian dan pembahasan dapat disimpulkan bahwa pembelajaran dengan menggunakan alat peraga sederhana berbasis pendekatan sains teknologi dan masyarakat pada materi fluida statis dapat efektif diterapkan pada mahasiswa. Hal ini dilihat dari hasil keterlaksanaan RPP yang berkategori baik, aktivitas mahasiswa yang dominan melakukan praktikum, hasil belajar mahasiswa rata-rata memiliki nilai 82, respon mahasiswa yang sangat baik terhadap penggunaan alat peraga sederhana fluida statis. 


\section{Ucapan Terimakasih}

Ucapan terimakasih ditujukan kepada Allah SWT yang memberikan rahmat serta hidayahnya sehingga penelitian ini dapat terselesaikan tepat waktu. Ucapan terimakasih juga disampaikan kepada Lembaga Penelitian dan Pengabdian pada Masyarakat Universitas KH. A. Wahab Hasbullah yang telah turut serta dalam keterlaksanaan kegiatan penelitian ini. Ucapan terimakasih disampaikan kepada semua pihak yang sudah mendukung pelaksanaan penelitian.

\section{Kepustakaan}

[I] Arifin, Mulyati,dkk., Stretegi Belajar Mengajar Kimia. Common Textbook (Edisi Revisi) . Bandung: Jurusan Pendidikan Kimia FMIPA UPI, 201 I.

[2] Pramesty, R. I., Pengembangan Alat Peraga Kit Fluida Statis Sebagai Media Pembelajaran Pada Sub Materi Fluida Statis di Kelas XI IPA SMA Negeri I Mojosari, Mojokerto, Inovasi Pendidikan Fisika, Vol.2, No.3, 2013.

[3] Poedjiadi, A., Sains teknologi masyarakat. Bandung: PT. Remaja Rosdakarya Offset, 2010

[4] Sugiyono., Metode Penelitian Pendidikan Pendekatan Kuantitatif, Kualitatif, dan R \&D. Bandung: Alfabeta, 2009.

[5] Abdullah, A., Oviana, W., \& Khatimah, H., Penggunaan Alat Peraga dari Bahan Bekas dalam Menjelaskan Sistem Respirasi Manusia di MAN Sawang Kabupaten Aceh Selatan, Jurnal Biologi Edukasi, Vol.3, No.3, 5I-55.

[6] Tri, Hendrik dkk, Pengembangan Alat Peraga Resonator sebagai Alternatif Media Pembelajaran pada Materi Gelombang Bunyi Kelas XII SMA, Radiasi,Vol.3, No.2, 2013.

[7] Inayah,Husnul dkk, Pengaruh Penggunaan Media Alat Peraga Terhadap Hasil Belajar Siswa pada Materi Sistem Peredaran Darah Kelas VIII SMP Negeri 2 Bulukumba, Jurnal Sainsmat, Vol. IV, No. I, 20I5, 7-I3

[8] Afriyanto, E., Pengembangan Media Pembelajaran Alat Peraga pada Materi Hukum Biot Savart di SMA Negeri I Prambanan Klaten., JRKPF UAD, Vol.2 No.I, 2015

[9] Rusmansyah, Irhasyuarna, Y., Implementasi Pendekatan SainsTeknologi-Masyarakat (STM) dalam Pembelajaran Kimia di SMU N Banjarmasin., Jurnal Pendidikan dan Kebudayaan., Vol.9, No.40, 2003, 95-109.

[10] Widiyatmoko, A., \& Pamelasari, S. D., Pembelajaran berbasis proyek untuk mengembangkan alat peraga IPA dengan memanfaatkan bahan bekas pakai, Jurnal Pendidikan IPA Indonesia, Vol.I, No.I, 2012. 